\title{
Regional and inter-annual trends in marine growth of juvenile salmon in coastal pelagic ecosystems of British Columbia, Canada
}

\author{
Bridget E. Ferriss ${ }^{1}$, Marc Trudel ${ }^{2,3}$, Brian R. Beckman ${ }^{4, *}$ \\ ${ }^{1}$ School of Aquatic and Fishery Sciences, University of Washington, Box 355020, Seattle, Washington 98195, USA \\ ${ }^{2}$ Pacific Biological Station, Fisheries and Oceans Canada, 3190 Hammond Bay Road, Nanaimo, British Columbia V9T 6N7, \\ Canada \\ ${ }^{3}$ Department of Biology, University of Victoria, British Columbia V8W 3N5, Canada \\ ${ }^{4}$ NOAA Fisheries, Northwest Fisheries Science Center, 2725 Montlake Blvd. East, Seattle, Washington 98112-2097, USA
}

\begin{abstract}
We measured insulin-like growth factor 1 (IGF1) concentrations (a proxy for growth) from juvenile coho Oncorhynchus kisutch, sockeye O. nerka, chum O. keta, and Chinook salmon O. tshawytscha collected in 8 regions of British Columbian coastal waters, in June of 2009, 2010, and 2011. We found annual differences in IGF1 for all 4 species, as well as species-specific regional differences in IGF1 concentrations in coho, chum, and sockeye salmon. Sockeye and chum salmon had consistently higher levels in the northern regions of the Dixon Entrance, Haida Gwaii, Hecate Strait, and lower levels in Queen Charlotte Strait. Regional differences in coho, chum, and sockeye salmon were highly correlated $\left(R^{2}=0.61-0.75\right)$. These results demonstrate that salmon growth responds to local environmental variability on a scale of several hundred kilometers. Thus, IGF1 measures should generate insight into fish production on relatively local regional and temporal scales, and these same measures may allow the assessment of how habitats vary on these same scales.
\end{abstract}

KEY WORDS: Oncorhynchus $\cdot$ IGF1 $\cdot$ Spatial $\cdot$ Scale $\cdot$ Ecosystem assessment $\cdot$ Hormone

\section{INTRODUCTION}

The role of bottom-up processes in regulating the productivity and abundance of marine pelagic populations is currently under debate (Hunt \& McKinnell 2006, Frank et al. 2007). This paradigm of food resource limitation driving population dynamics in marine systems suggests that abundant food resources lead to rapid growth, increased survival, and relatively higher abundance of any given population (Steele 1974, Cushing 1975). Evaluating the regulatory influence of bottom-up forcing on fish production requires determining the linkages between different trophic levels and may depend on correlative

\footnotetext{
${ }^{*}$ Corresponding author: brian.beckman@noaa.gov
}

analyses between indices of abundance such as chlorophyll a ( $\mathrm{chl}$ a) concentration (phytoplankton abundance) and fish abundance (Ware \& Thomson 2005). These kinds of correlations may not reveal mechanisms regulating fish populations, as abundance may not directly reflect variation in the processes of food consumption and growth.

It is not easy to measure growth (change in size) of populations of free-living fish. The most straightforward approach, i.e. measuring size of individual fish at a geographic location through time and determining differences in mean size, requires meeting assumptions of limited immigration and emigration, and in addition, limited size-selective mortality.

(C) Ferriss and Fisheries and Oceans Canada 2014. Open Access under Creative Commons by Attribution Licence. Use, distribution and reproduction are unrestricted. Authors and original publication must be credited. Publisher: Inter-Research · www.int-res.com 
These assumptions may be difficult to meet in large, open marine systems. Methods that utilize size at age increments recorded in hard body parts, such as scales or otoliths, require similar assumptions. An instantaneous measure of growth would allow one to directly test inferences about population-level relationships between prey abundance, consumption, growth, and mortality of fish in a given area at a given time. The ability to simultaneously measure fish growth rate and environmental characteristics can provide an ecosystem-scale snapshot of growth rate that is not complicated by size-selective mortality and other factors affecting growth estimates through time.

Herein we report on levels of the hormone insulinlike growth factor 1 (IGF1), an index of fish growth (Beckman 2011), from juvenile salmon caught off the coast of British Columbia (BC), Canada. Juvenile salmon are widely spread throughout the coastal regions of BC (Fisher et al. 2007), and their physiological status might provide a broad-scale perspective on ecosystem processes in these regions. IGF1 is a protein that circulates in the blood and is a primary component of the endocrine growth axis in all vertebrates, directly stimulating cells to divide and grow (Kostyo \& Goodman 1999). Plasma levels of IGF1 are linearly related to specific growth rates of individual juvenile salmon (Beckman et al. 2004a,b) over a time period of 1 to $2 \mathrm{wk}$ within a specific seasonal period. However, the slope of IGF1 versus growth relations may vary between seasons (summer versus autumn, Beckman et al. 2004b). Thus, IGF1 can provide an instantaneous snapshot of relative fish growth during a specific seasonal period, but IGF1 levels do not provide a direct estimate of growth rate. Nevertheless, IGF1 measures provide the ability to both directly compare growth of fish caught in different locations and to relate growth of fish caught in a given location to in situ environmental conditions.

$\mathrm{BC}$ coastal waters are within a transition zone between the California Current ecosystem to the south and the Gulf of Alaska ecosystem to the north, formed by the actions of the North Pacific Current splitting as it moves eastward to the margins of North America. The region is characterized by the weak influence of major ocean currents (California and Alaska Currents), allowing local environmental drivers such as coastal topography and freshwater inputs to contribute to variation in productivity (Crawford \& Thomson 1991). This small-scale variability in ocean and food web dynamics translates into regional differences in zooplankton abundance (Mackas et al. 2001) and juvenile salmon diet (Brodeur et al. 2007) and could result in differences in juvenile salmon prey consumption and growth. Indeed, Perry et al. (1996) found spatial differences in diet and body condition of pink and chum salmon off the west coast of Vancouver Island.

We have generated a 3 yr data set (2009 to 2011) of IGF1 levels in juvenile coho Oncorhynchus kisutch, chum $O$. keta, sockeye $O$. nerka, and Chinook salmon $O$. tshawytscha from BC coastal waters. Using these data, we determined whether salmon growth varies annually and spatially along the $\mathrm{BC}$ coast, and whether there are inter-specific differences in these trends. This analysis is unique in its ability to directly relate growth of juvenile salmon to the specific region in which they were captured. This data set allows us to take the initial steps in validating IGF1 as a tool with which to investigate ecosystem processes in the marine pelagic environment.

\section{MATERIALS AND METHODS}

\section{Data collection}

We collected data during 3 research cruises (1 cruise $\mathrm{yr}^{-1}$ for 3 consecutive years) in 2009 (17 June to 2 July), 2010 (16 June to 2 July), and 2011 (15 June to 4 July) in the coastal and shelf waters of BC (Fig. 1). Our sample regions included the outer coastal and shelf waters off Vancouver Island and Haida Gwaii, the inner coastal waters of Queen Charlotte Strait and Hecate Strait, and the 2 main connections between the Pacific and inner waters: Dixon Entrance and Queen Charlotte Sound. These regions vary oceanographically with regard to the influence of Pacific Ocean currents versus freshwater runoff. We separated the outer Vancouver Island waters into north, mid-, and south Vancouver Island regions at $48.9^{\circ}$ and $49.5^{\circ} \mathrm{N}$ (Fig. 1). These divisions allowed us to observe potential differences in salmon growth due to spatial variability in oceanography (Crawford \& Thomson 1991) and diet (Perry et al. 1996). The sample stations (trawl locations within sample regions) were not geographically identical or numerically equivalent across the 3 years (Fig. 1; 2009: 79 stations, 2010: 80 stations, 2011: 89 stations), but similar regional coverage was accomplished in each year.

Four different species of juvenile salmon, viz. coho, sockeye, chum, and Chinook, were sampled. Pink salmon Oncorhynchus gorbuscha were also caught in the trawls but were not analyzed in this study. Juveniles from each of these species exhibit differing life histories; specifically, they enter marine waters at 


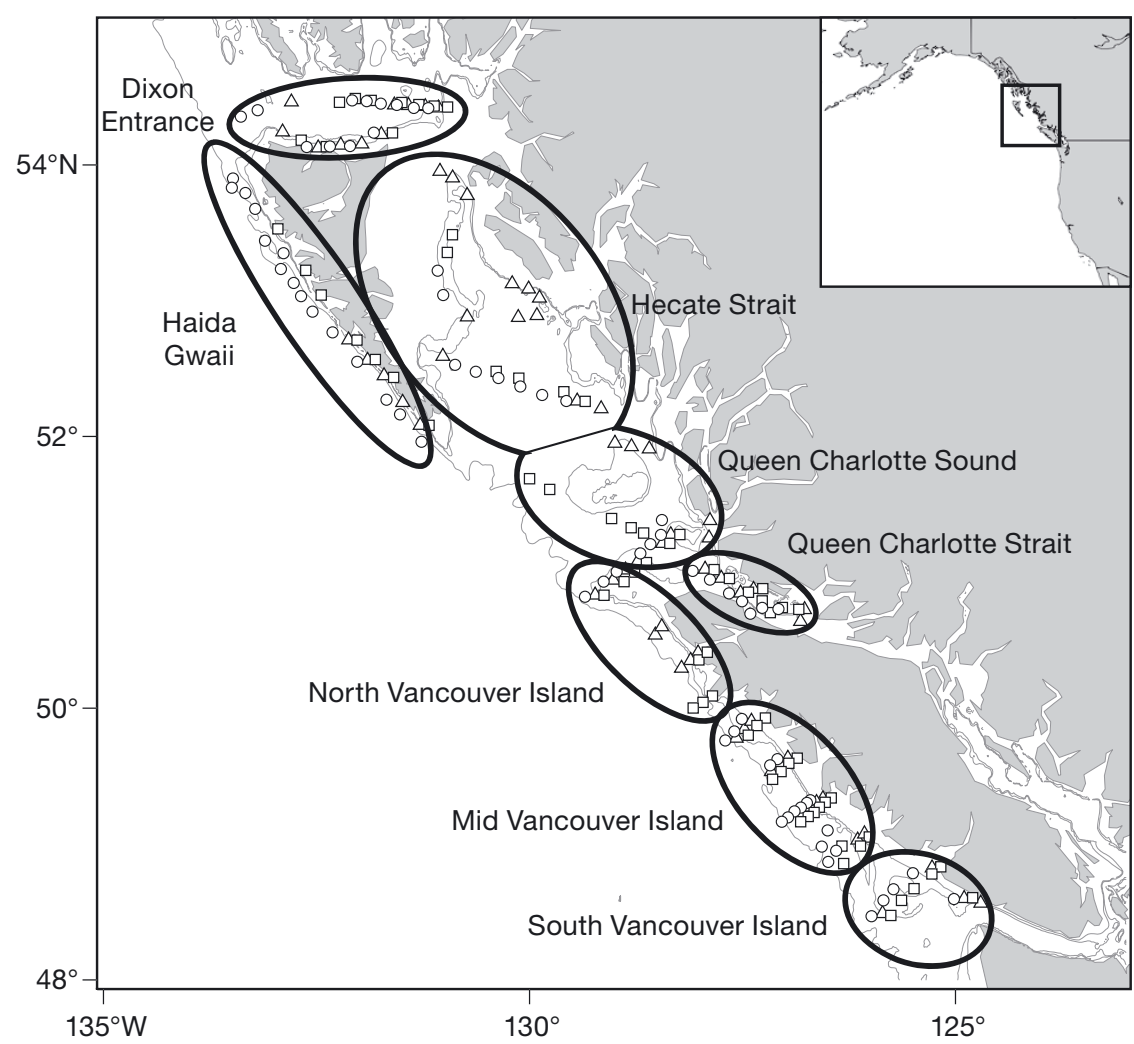

Fig. 1. Oncorhynchus spp. Trawl locations (O: 2009; $\square: 2010 ; \Delta: 2011$ ) and regions (large open ellipses) for coho, Chinook, sockeye, and chum salmon analyzed in this study. Symbols for 2009 and 2010 are offset from true sample location by $0.1^{\circ}$ east and west, respectively

different ages and sizes with differing seasonal timing (Groot \& Margolis 1991). The following size criteria were generated from coded-wire tags and nonoverlapping frequency distributions and were used to ensure that we only sampled juvenile fish that were in their first few weeks to months of ocean residence: coho salmon $<350 \mathrm{~mm}$, Chinook salmon $<275 \mathrm{~mm}$, sockeye salmon $<300 \mathrm{~mm}$, chum salmon $<300 \mathrm{~mm}$ (Trudel et al. 2007a).

We conducted a surface tow $(0-20 \mathrm{~m})$ at each station using a modified mid-water trawl. A hexagonal mesh mid-water rope trawl $(\sim 90 \mathrm{~m}$ long $\times 30 \mathrm{~m}$ wide $\times 18 \mathrm{~m}$ deep, cod-end mesh $0.6 \mathrm{~cm}$; Cantrawl Pacific) was trawled for 15 to $30 \mathrm{~min}$ at 5 knots between 07:00 and 19:00 h. Up to 20 juveniles of each species were sampled for blood from each trawl (catch of a given species in any one trawl ranged from 0 to $>500$ ). From these juvenile salmon, we collected 0.1 to $0.3 \mathrm{ml}$ blood from the ventral side of the caudal peduncle using a heparinized syringe. The blood sample was immediately chilled on ice and centrifuged (micro-centrifuge at $3000 \times g$, $5 \mathrm{~min}$ ) within $8 \mathrm{~h}$. The plasma was removed and stored at $-20^{\circ} \mathrm{C}$ while at sea (up to $20 \mathrm{~d}$ ) and at $-80^{\circ} \mathrm{C}$ in the laboratory.

IGF1 was measured using a timeresolved fluorescence immunoassay (Small \& Peterson 2005) based on a dissociation enhanced lanthanide fluorescence immunoassay (DELFIA ${ }^{\circledR}$, Perkin Elmer) methodology. Recombinant salmon IGF1 was used as a standard, and polyclonal rabbit antirecombinant barramundi IGF1 serum (GroPep) was used as a primary antibody. Tracer was produced by custom labeling of the recombinant salmon IGF1 (GroPep) with europium (Perkin Elmer BioSignal). Reactions were carried out in DELFIA ${ }^{\circledR}$ Assay Buffer in goat anti-rabbit IGG-coated yellow 96-well plates (Perkin Elmer) incubated at $4^{\circ} \mathrm{C}$ with constant shaking. Sample or standard and anti-IGF were incubated prior to the addition of tracer, then incubated overnight again before the final fluorescence reaction and reading. Reactions included an empirically determined volume of plasma extract (Shimizu et al. 2000), anti-IGF diluted to a final dilution 1:62 000, and Eu-IGF1 tracer at a final concentration of $0.571 \mathrm{ng}$ $\mathrm{ml}^{-1}$ in a total reaction volume of $175 \mu \mathrm{l}$. On the third day, plates were washed 5 times and shaken vigorously for $10 \mathrm{~min}$ at room temperature with $100 \mu \mathrm{l}$ of DELFIA ${ }^{\circledR}$ Enhancement solution to cause dissociation of the europium label, which forms a fluorescent lanthanide-chelate. Fluorescence levels were measured using a Victor3 1420 Multilabel Counter (Perkin Elmer Life and Analytical Sciences, Wallac Oy). Data were processed with WorkOut2 software (Dazdaq) using a 4-parameter logistic equation to fit the standard curve.

IGF1 levels are reported as the mean of duplicate measurements. Samples were re-measured or excluded from analysis if the coefficient of variation exceeded $10 \%$ and there was $>10 \mathrm{ng} \mathrm{ml}^{-1}$ difference between duplicates. To account for inter-assay variation in standard curves, an inter-assay pool (IP) of plasma was measured in every assay at 3 concentrations within the linear portion of the standard curve that translate to 20,50 , and $80 \%$ of maximal tracer binding. A linear regression of the IP concentrations versus their percent binding was created for every subsequent assay and compared to the original slope 
of this regression. Sample values for a given run of the assay were standardized by the slope and intercept of the $\mathrm{IP}_{\text {original assay }}$ versus $\mathrm{IP}_{\text {new assay }}$ regression equation. This method was used to standardize between assay runs within a collection year and between years. To avoid bias in the data generated by technical differences between assay runs, all samples collected within a given year were randomly distributed among assay runs.

In addition, it was necessary to determine whether any maturing male (jack) salmon were part of the sample, as androgens produced in the maturation process strongly stimulate plasma IGF-I levels and disrupt IGF1-growth relations (Beckman et al. 2004b, Larsen et al. 2004). Thus, each sample was assessed for 11-ketotestosterone (11-KT), the primary androgen stimulating male maturation in salmonids (Cuisset et al. 1994). Fish with 11-KT values $>1.5 \mathrm{ng} \mathrm{ml}^{-1}$ were removed from further analysis.

\section{Statistical analysis}

\section{IGF1 size adjustment}

We addressed 2 potential issues with the IGF1 data. It is easier to obtain blood from large fish (>200 $\mathrm{mm}$ ) than small fish $(<120 \mathrm{~mm})$; thus sampling error might occur due to inadvertent selection of larger fish for bleeding. Therefore, we tested for size differences between bled and non-bled fish by calculating the difference between average fork length of bled fish and that of all juveniles caught in each haul, and conducted an ANOVA to determine whether the differences in mean lengths varied by region, for each species. Length was included as a fixed effect in the subsequent analysis of regional differences for a species (see below) if significant differences in length were found.

In addition, we addressed potential size effects in the IGF1 values due to differing fish sizes. Shimizu et al. (2009) found a small, yet significant and positive relationship between IGF1 levels and length in fasted coho salmon, suggesting that basal IGF1 levels differ with size. In order to isolate the growth-related IGF1 signal, we adjusted the measured IGF1 value of all species for differences in size-based basal IGF1 values (Shimizu et al. 2009):

$$
\mathrm{IGF}_{\text {Sadj }}=\mathrm{IGF}_{\text {obs }}-4+0.07 \text { (Length) }
$$

where IGF1 $1_{\text {Sadj }}\left(\mathrm{ng} \mathrm{m} \mathrm{m}^{-1}\right)$ represents IGF1 values corrected for size-related basal IGF1, IGF1 $1_{\text {obs }}\left(\mathrm{ng} \mathrm{ml}^{-1}\right)$ represents the IGF1 values measured in this study, and length (mm) is fork length. We used these adjusted data for all further analyses (see Table 4).

Body condition index

We assessed whether IGF1 $1_{\text {Sadj }}$ was related to either length or body condition index for each species using linear regression. Body condition indices were calculated by applying a linear regression to the natural log transformed length and body mass of individual fish, combined across all years and regions for each species (Jakob et al. 1996, Brodeur et al. 2004). The residuals of the observed mass relative to predicted mass (based on the length to weight regression) formed each species-specific index. Individual body condition index values were regressed against corresponding mean IGF1 $1_{\text {Sadj }}$ values to determine the relationship between IGF1 $1_{\text {Sadj }}$ and body condition.

\section{Regional differences}

We used mixed-effects multiple regression models (fixed and random effects) in the $\mathrm{R}$ programming environment to test for yearly, species-specific differences in IGF1 $1_{\text {Sadj }}$ concentrations at a regional scale (as defined in Fig. 1) as follows:

$$
\begin{gathered}
\ln \left(\text { IGF }_{\text {Sadj (iyrs) })}\right)=\beta_{0}+\beta_{1} \text { Length }_{i}+\beta_{2} \text { Year }_{y}+ \\
\beta_{3} \text { Region }_{r}+b \text { Station }_{s}+\varepsilon_{(i y r s)}
\end{gathered}
$$

We first combined 2009, 2010, and 2011 IGF1 $_{\text {Sadj }}$ data, for each species, to determine whether IGF $1_{\text {Sadj }}$ values varied by year (i) and region $(j)$. We natural $\log$ transformed the $\mathrm{IGF} 1_{\text {Sadj }}$ data to satisfy the assumption of homogeneity of variance and normality. In the above equation, $\ln \left(I G F_{S a d j(i y r s)}\right)$ represents the natural $\log$ transformed IGF1 $1_{\text {Sadj }}$ values of individual (i) at station ( $s$ ), in region $(r)$ and year $(y)$. Fork length (Length) was included as a fixed effect in the sockeye and chum models only (see 'Results'). In each species-specific model, we included sample station $(s)$ as a random effect (with coefficient $b$ ), accounting for the covariation shared by fish caught in the same haul. $\beta$ represents fixed-effect coefficients. The term $\varepsilon_{(i y r s)}$ is a normally distributed error. We compared the fit of the models with multiple combinations of year and region as fixed effects using Akaike's information criterion corrected for small sample size $\left(\mathrm{AIC}_{\mathrm{C}}\right.$, Burnham \& Anderson 2002) to determine which model best explained the variation in $\mathrm{IGF} 1_{\text {Sadj }}$ values. 


\section{RESULTS}

\section{IGF1-size standardization}

The lengths of sampled fish ranged from 103 to $350 \mathrm{~mm}$ (coho), 118 to $275 \mathrm{~mm}$ (Chinook), 98 to $217 \mathrm{~mm}$ (sockeye), and 112 to $188 \mathrm{~mm}$ (chum) (regional averages shown in Table 1). We compared pre- and post-standardized IGF1 values to length values to show how the data changed with the removal of the basal IGF1 level. Unstandardized IGF1 values were significantly and positively related to length for each species, with a relatively low proportion of the variance in individual IGF1 values explained by differences in length $\left(\mathrm{R}^{2}=0.10-0.22\right.$, Fig. 2). After standardizing for basal IGF1 levels, IGF1 $1_{\text {Sadj }}$ values were still significantly related to length measurements of coho, Chinook, sockeye, and chum salmon, but the proportion of the variance in individual IGF1 $1_{\text {Sadj }}$ values explained by differences in length was small $\left(p<0.001, R^{2}=0.04-0.14\right.$, Fig. 2).
There were significant differences in mean body length between juvenile salmon caught in the trawl and those sub-sampled for IGF1 for sockeye (2009) and chum salmon (2009-2011), but no significant differences were found for either coho or Chinook salmon (Table 2). Most of the average length differences (bled versus captured) were less than $10 \mathrm{~mm}$, resulting in a predicted 2 to $3 \mathrm{ng} \mathrm{ml}^{-1}$ difference in IGF1 $1_{\text {Sadj }}$ (Table 3). We took a conservative approach in analyzing for regional differences in sockeye (2009) and chum salmon (2009-2011) IGF1 $1_{\text {Sadj }}$ concentrations by accounting for sampling error for size in mixed-effect models.

\section{Body condition index}

IGF1 $1_{\text {Sadj }}$ was significantly correlated to the body condition index for coho, Chinook, and sockeye salmon; however the correlation coefficients were very low $\left(p<0.001, R^{2}=0.04-0.1\right.$, Fig. 3 ). No significant relation between body condition index and IGF $1_{\text {Sadj }}$ was found for chum salmon $(p=0.11$, Fig. 3$)$.

Table 1. Oncorhynchus spp. Regional summary of mean (SD) length (mm) and sample size (n) of coho, Chinook, sockeye, and chum salmon collected from 2009 through 2011; na: not available

\begin{tabular}{|c|c|c|c|c|c|c|c|c|c|}
\hline \multirow[t]{2}{*}{ Region } & \multirow[t]{2}{*}{ Year } & \multicolumn{2}{|c|}{ Coho } & \multicolumn{2}{|c|}{ Chinook } & \multicolumn{2}{|c|}{ Sockeye } & \multicolumn{2}{|c|}{ Chum } \\
\hline & & Length & $\mathrm{n}$ & Length & $\mathrm{n}$ & Length & $\mathrm{n}$ & Length & $\mathrm{n}$ \\
\hline \multirow[t]{3}{*}{ Dixon Entrance } & 2009 & $210(24)$ & 51 & $250(19)$ & 5 & $164(22)$ & 25 & na & na \\
\hline & 2010 & $201(26)$ & 65 & $204(28)$ & 4 & 159(18) & 19 & 148(na) & 1 \\
\hline & 2011 & $200(25)$ & 13 & $221(32)$ & 7 & $177(13)$ & 13 & 176(na) & 1 \\
\hline \multirow[t]{3}{*}{ Hecate Strait } & 2009 & $208(30)$ & 66 & 191(17) & 65 & $159(15)$ & 54 & $150(10)$ & 14 \\
\hline & 2010 & $204(21)$ & 24 & $177(12)$ & 8 & na & 29 & 159(18) & 6 \\
\hline & 2011 & $177(26)$ & 52 & 190(16) & 26 & 148(13) & 53 & 148(17) & 38 \\
\hline \multirow[t]{3}{*}{ Haida Gwaii } & 2009 & 218(29) & 37 & $238(21)$ & 33 & 164(18) & 44 & $160(8)$ & 4 \\
\hline & 2010 & 220(33) & 2 & $227(19)$ & 26 & $158(4)$ & 3 & na & na \\
\hline & 2011 & 242(19) & 10 & $230(24)$ & 12 & 153(na) & 1 & na & na \\
\hline \multirow[t]{3}{*}{ Queen Charlotte Sound } & 2009 & 186(11) & 3 & 184(13) & 2 & $120(6)$ & 35 & 136(7) & 23 \\
\hline & 2010 & $177(17)$ & 7 & 184(8) & 2 & 134(13) & 47 & 146(12) & 36 \\
\hline & 2011 & $187(24)$ & 14 & 194(26) & 9 & $132(10)$ & 52 & $146(14)$ & 35 \\
\hline \multirow[t]{3}{*}{ Queen Charlotte Strait } & 2009 & 195(18) & 33 & na & na & $124(8)$ & 31 & 141(10) & 31 \\
\hline & 2010 & $187(22)$ & 45 & 166(na) & 1 & $128(9)$ & 27 & 142(12) & 25 \\
\hline & 2011 & 184(13) & 33 & $187(17)$ & 3 & $130(6)$ & 19 & 141(9) & 31 \\
\hline \multirow[t]{3}{*}{ North Vancouver Island } & 2009 & $184(24)$ & 59 & $177(23)$ & 45 & 136(14) & 27 & 131(8) & 23 \\
\hline & 2010 & $210(15)$ & 59 & 181(22) & 102 & $128(16)$ & 43 & 139(13) & 23 \\
\hline & 2011 & $205(22)$ & 46 & $190(24)$ & 68 & 137(18) & 28 & 141(15) & 22 \\
\hline \multirow[t]{3}{*}{ Mid-Vancouver Island } & 2009 & 181(19) & 99 & $170(20)$ & 45 & 140(10) & 36 & 129(8) & 28 \\
\hline & 2010 & $206(21)$ & 15 & $175(18)$ & 76 & $124(7)$ & 17 & $137(12)$ & 4 \\
\hline & 2011 & $188(17)$ & 24 & 192(28) & 14 & $135(20)$ & 8 & 130(11) & 12 \\
\hline \multirow[t]{3}{*}{ South Vancouver Island } & 2009 & $165(21)$ & 34 & $172(26)$ & 9 & $131(8)$ & 4 & 125(na) & 1 \\
\hline & 2010 & $179(27)$ & 50 & $204(44)$ & 5 & 118(11) & 4 & 149(2) & 2 \\
\hline & 2011 & 148(17) & 9 & $217(35)$ & 20 & $100(2)$ & 3 & 127(13) & 2 \\
\hline
\end{tabular}




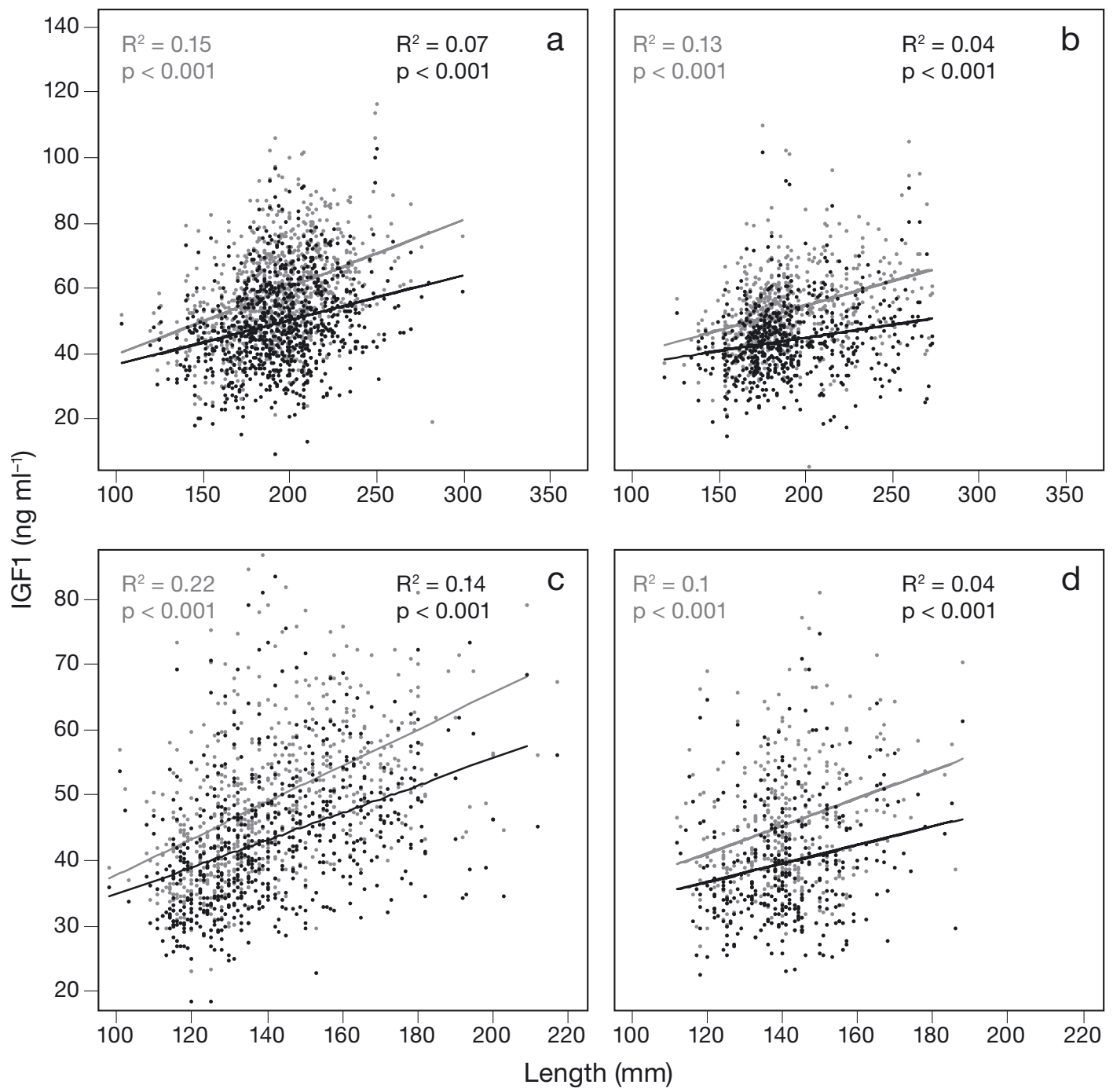

Fig. 2. Oncorhynchus spp. Insulin-like growth factor 1 (IGF1, $\mathrm{ng} \mathrm{ml}^{-1}$; gray) and size-adjusted IGF1 (IGF1 $1_{\mathrm{Sadj}}$, black) versus length (mm) for (a) coho salmon, (b) Chinook salmon, (c) sockeye salmon, and (d) chum salmon from 2009 to 2011 . Note the different scales between the upper and lower plots. Correlation coefficients and p values correspond to original (gray font) and size-adjusted (black) IGF1 levels

\section{IGF1 variation}

The best-fit models for sockeye, chum, and coho salmon (year and region as fixed effects) explained a relatively large amount of variation in IGF1 $1_{\text {Sadj }}$ values (coho salmon: $\mathrm{R}^{2}=$ 0.33 , sockeye salmon: $\mathrm{R}^{2}=0.59$, chum salmon: $\mathrm{R}^{2}=0.55$; see Table 5 ). The highest IGF1 $1_{\text {Sadj }}$ values occurred in 2011 for all 4 salmon species (with some regional exceptions for coho salmon), relative to 2009 and 2010 .
Table 2. Oncorhynchus spp. Results of the ANOVA tests determining whether sampling bias occurred. Specifically, differences in mean lengths between total juvenile salmon caught were compared to the mean lengths of those subsampled, for each species, and it was determined whether these differences varied significantly by region. The $F$ statistic, $\mathrm{p}$ value, and $\mathrm{df}$ (between groups, within groups) are given

\begin{tabular}{|lcccccccccc|}
\hline & \multicolumn{3}{c}{$\begin{array}{c}2009 \\
\mathrm{df}\end{array}$} & $\mathrm{p}$ & $F$ & $\begin{array}{c}2010 \\
\mathrm{df}\end{array}$ & $\mathrm{p}$ & $F$ & $\begin{array}{c}2011 \\
\mathrm{df}\end{array}$ & $\mathrm{p}$ \\
\hline Coho & 0.3 & 7,48 & 0.9 & 2.3 & 6,35 & 0.06 & 0.3 & 7,33 & 0.9 \\
Chum & 2.6 & 6,26 & 0.04 & 3.1 & 5,19 & 0.03 & 9,5 & 5,18 & $<0.001$ \\
Sockeye & 2.5 & 6,26 & $<0.001$ & 0.8 & 7,39 & 0.6 & 1 & 7,26 & 0.5 \\
Chinook & 1.5 & 5,33 & 0.2 & 0.8 & 7,33 & 0.6 & 1.17 & 7,32 & 0.4 \\
\hline
\end{tabular}


Table 3. Oncorhynchus nerka and O. keta. Differences in mean length ( $\mathrm{mm}$ ) between salmon subsampled for insulin-like growth factor 1 (IGF1) analysis and all juveniles caught per station for sockeye and chum salmon from 2009 to 2011. Length bins are defined as greater than the lower value and equal to or less than the upper value. Predicted differences in IGF1 are based on the species-specific IGF-length relationship calculated in Fig. 2. As an example, a difference in length of 20-25 mm between sockeye salmon subsampled and analyzed for IGF and the mean length of all sockeye salmon caught in the trawl would result in a predicted IGF1 difference of $6.8 \mathrm{ng} \mathrm{l}^{-1}$. This particular difference in length (20-25 mm) was found in $4 \%$ (2009), $0 \%$ (2010), and $3 \%$ (2011) of all stations for sockeye salmon

\begin{tabular}{|c|c|c|c|c|c|c|c|c|}
\hline \multirow[t]{2}{*}{$\begin{array}{l}\text { Length bin } \\
(\mathrm{mm})\end{array}$} & \multicolumn{3}{|c|}{$\begin{array}{c}\text { Sockeye } \\
\% \text { stations within length bin }\end{array}$} & \multirow{2}{*}{$\begin{array}{c}\text { Predicted } \\
\text { difference } \\
\text { IGF1 }\left(\mathrm{ng} \mathrm{ml}^{-1}\right)\end{array}$} & \multicolumn{3}{|c|}{$\begin{array}{l}\text { Chum } \\
\text { \% stations within length bin }\end{array}$} & \multirow{2}{*}{$\begin{array}{c}\text { Predicted } \\
\text { difference } \\
\text { IGF1 }\left(\mathrm{ng} \mathrm{ml}^{-1}\right)\end{array}$} \\
\hline & 2009 & 2010 & 2011 & & 2009 & 2010 & 2011 & \\
\hline$<-5$ & 0 & 0 & 0 & -1.4 & 0 & 0 & 3 & -1.1 \\
\hline$-5-0$ & 52 & 74 & 62 & 0 & 28 & 43 & 55 & 0 \\
\hline $0-5$ & 14 & 9 & 24 & 1.4 & 17 & 17 & 10 & 1.1 \\
\hline $5-10$ & 14 & 13 & 9 & 2.7 & 14 & 20 & 10 & 2.2 \\
\hline $10-15$ & 9 & 2 & 0 & 4.1 & 17 & 7 & 7 & 3.4 \\
\hline $15-20$ & 5 & 0 & 0 & 5.4 & 14 & 10 & 3 & 4.5 \\
\hline $20-25$ & 4 & 0 & 3 & 6.8 & 6 & 3 & 7 & 5.6 \\
\hline $25-30$ & 2 & 0 & 0 & 8.2 & 3 & 0 & 0 & 6.7 \\
\hline $30-35$ & 0 & 2 & 3 & 9.5 & 3 & 0 & 3 & 7.8 \\
\hline
\end{tabular}

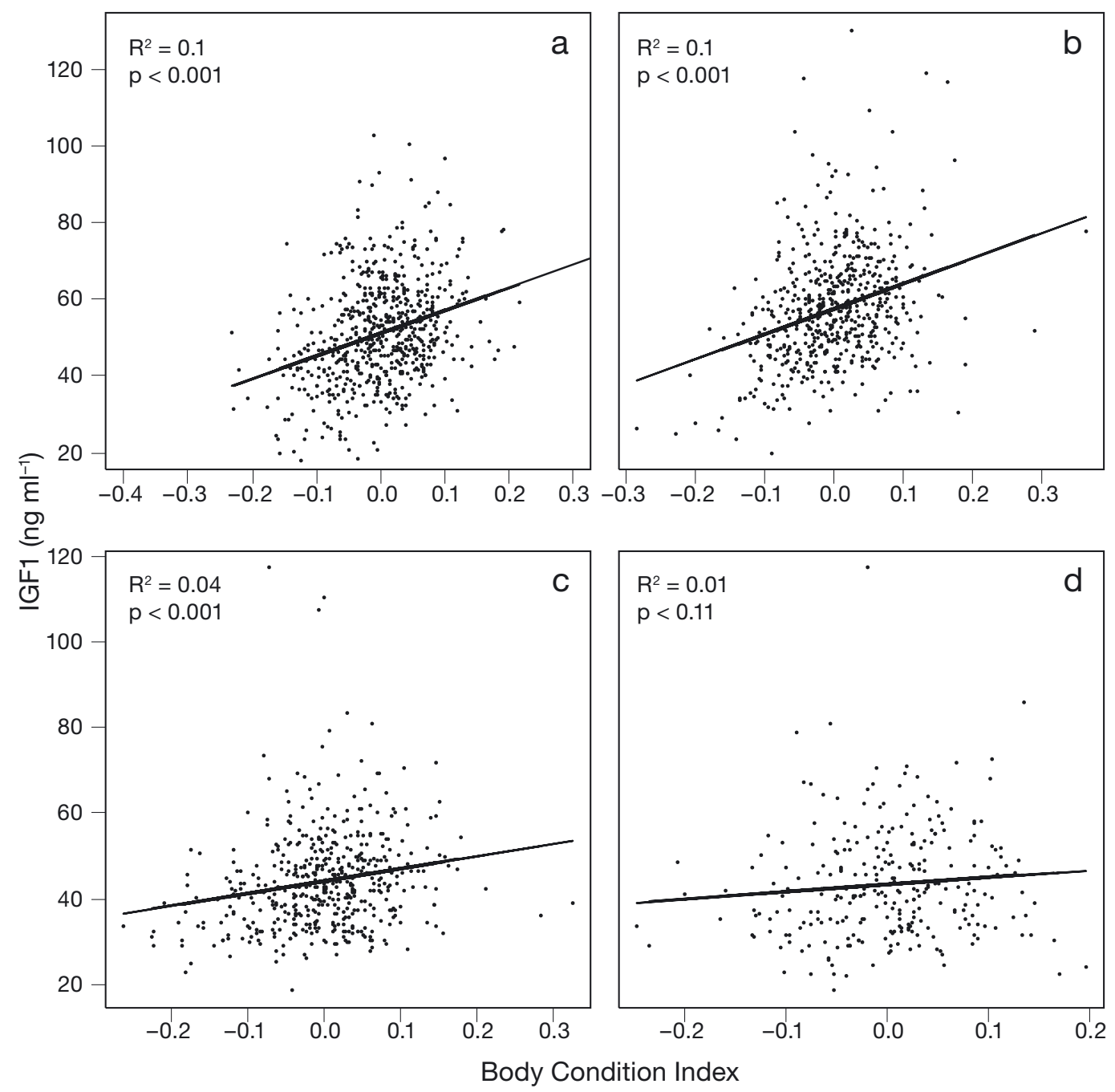

Fig. 3. Oncorhynchus spp. Size-adjusted insulin-like growth factor 1 (IGF1 $1_{\text {Sadj }}$ ) levels $\left(n g \mathrm{ml}^{-1}\right.$ ) versus body condition index for (a) coho salmon, (b) Chinook salmon, (c) sockeye salmon, and (d) chum salmon from 2009 to 2011 


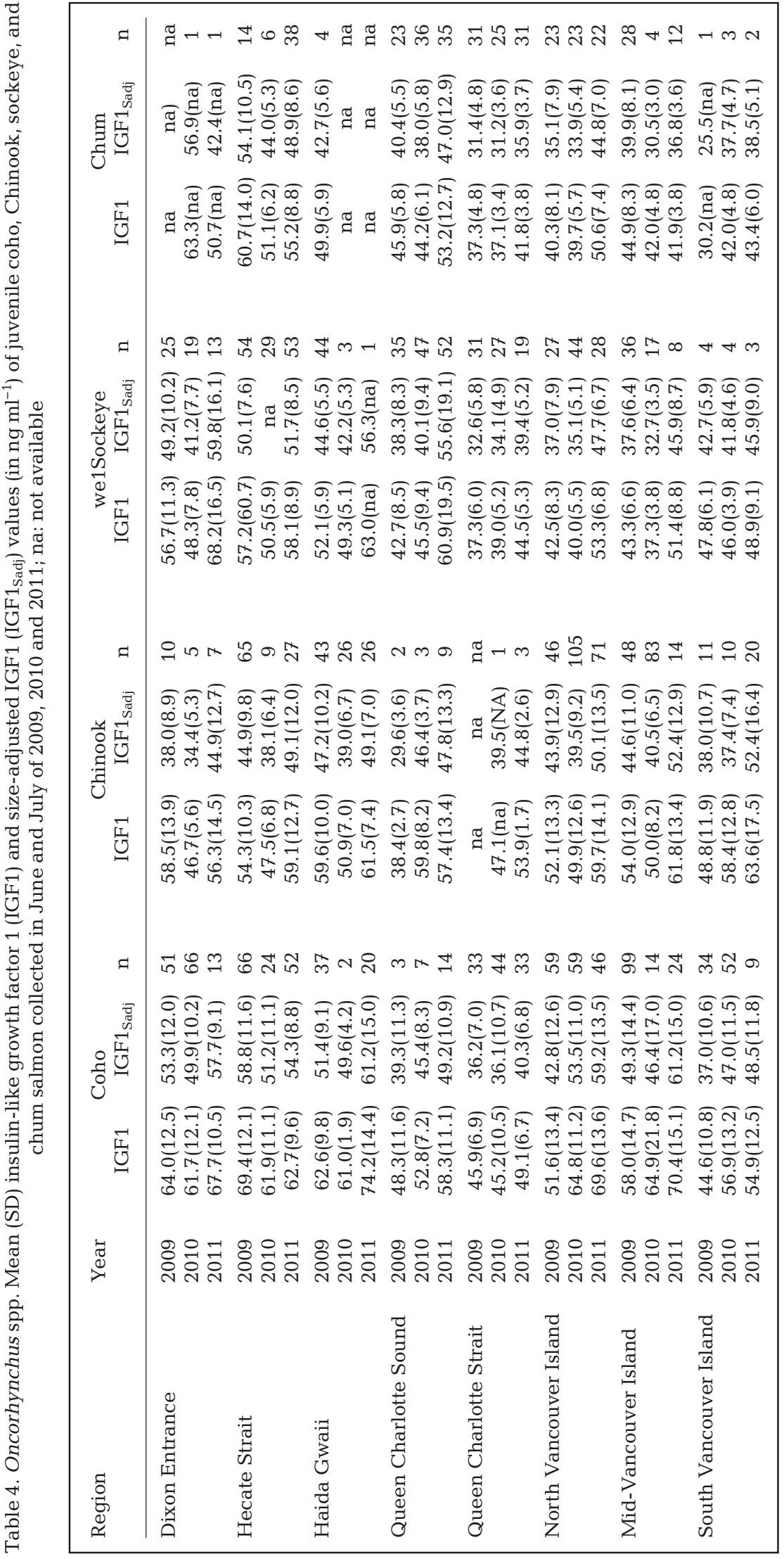

Regional trends in IGF1 $1_{\text {Sadj }}$ concentrations for sockeye and chum salmon were similar in 2009, 2010, and 2011 (Table 4, Figs. 4 \& 5), with levels typically higher in the northern regions of Dixon Entrance, Hecate Strait, and Haida Gwaii than found in other regions. Queen Charlotte Strait was associated with the lowest regional IGF1 $1_{\text {Sadj }}$ concentrations for coho, sockeye, and chum salmon. Coho salmon had more variable regional patterns in IGF1 $1_{\text {Sadj, }}$ with lower values in Queen Charlotte Strait, Queen Charlotte Sound, and South Vancouver Island.

IGF1 $1_{\text {Sadj }}$ concentrations of Chinook salmon varied little across regions within a year, but annual differences were found (Table 5, Figs. 4 \& 5). IGF1 $1_{\text {Sadj }}$ levels in Chinook salmon were highest in 2011 (similar to the other species) and lowest in 2010. The model with year as a fixed effect (and not region) best explained the variation observed in the IGF1 $1_{\text {Sadj }}$ value (Table 5). However, the correlation coefficients of the models were low $\left(\mathrm{R}^{2}=0.16-0.17\right)$, demonstrating the poor explanatory power of these models for Chinook salmon growth in these regions.

Sockeye, chum, and coho salmon IGF1 $1_{\text {Sadj }}$ levels were significantly correlated with each other $(p<0.01)$ over combined 2009, 2010, and 2011 regional averages. Chinook salmon IGF1 $1_{\text {Sadj }}$ was not significantly correlated with IGF $1_{\text {Sadj }}$ from any of the other species ( $p>0.05 ;$ Fig. 6 ). Sockeye and chum salmon IGF $1_{\text {Sadj }}$ levels were most closely correlated $\left(R^{2}=0.75\right)$, followed by the relationship between coho and sockeye salmon IGF1 $1_{\text {Sadj }}$ levels $\left(\mathrm{R}^{2}=\right.$ $0.67)$, and coho and chum salmon IGF1 $1_{\text {Sadj }}$ levels $\left(R^{2}=0.61\right.$; Fig. 6$)$.

\section{DISCUSSION}

We found significant regional differences in marine growth of juvenile coho, chum, and sockeye salmon sampled along the BC coast. Growth was consistently high in Hecate Strait and around Haida Gwaii, and consistently 


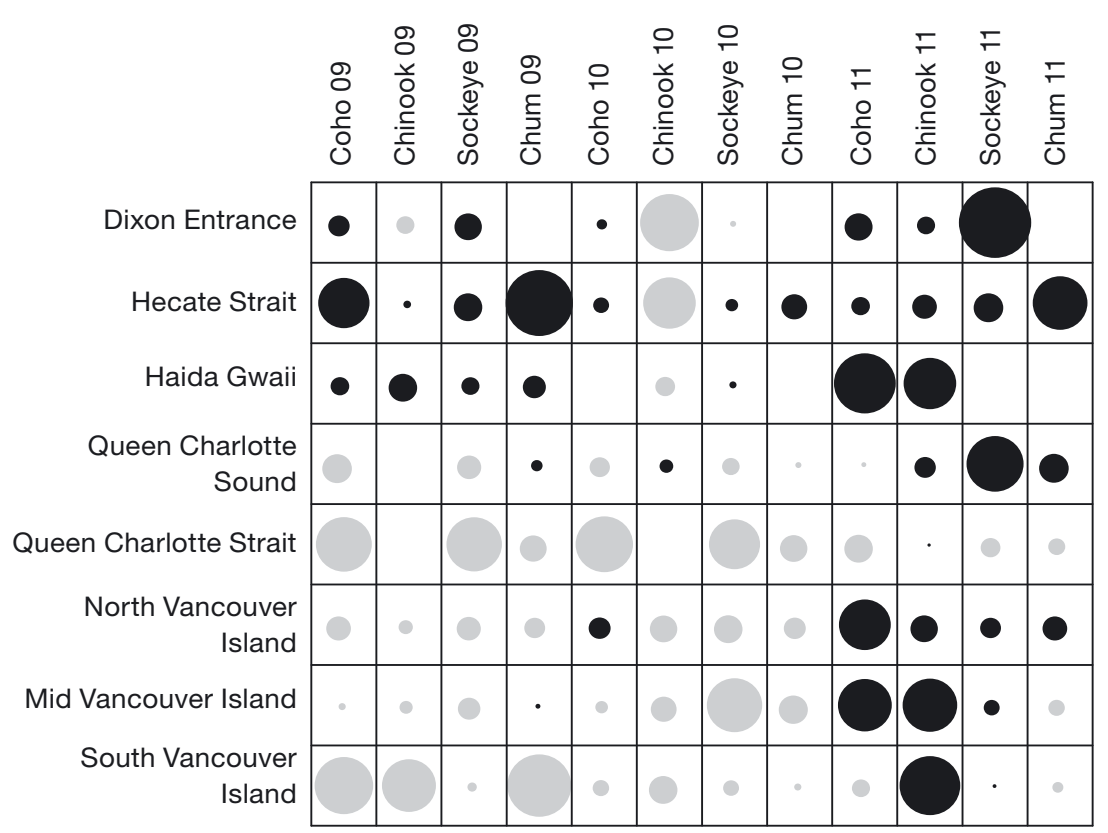

Fig. 4. Oncorhynchus spp. Regional means of standardized (Z-scores), size-adjusted insulin-like growth factor 1 (IGF1 $\left.1_{\text {Sadj }}\right)$ levels $\left(\mathrm{ng} \mathrm{ml}^{-1}\right.$ ) of coho, Chinook, sockeye, and chum salmon, from 2009, 2010, and 2011, as represented by the volume of the circles. Black represents positive levels (large black is highest IGF1) and gray represents negative levels (large gray is lowest IGF1) low in Queen Charlotte Strait across species and years. In contrast, relative growth varied between years and across species in Queen Charlotte Sound and off the west coast of Vancouver Island. Together these results present a mosaic of regionally and inter-annually varying fish growth, suggesting that the marine environment of juvenile salmon varies across these same geographic and temporal scales.

Variations in diet quantity and/or quality are the most likely explanation for our observed differences in IGF1 $1_{\text {Sadj. }}$ Regional- and annual-scale variation in the abundance, species composition, and trophic status of zooplankton has been found off the BC Coast (Mackas et al. 2001, Batten \& Walne 2011, El-Sabaawi et al. 2012). Similarly, salmon diets have been found to vary regionally off Vancouver

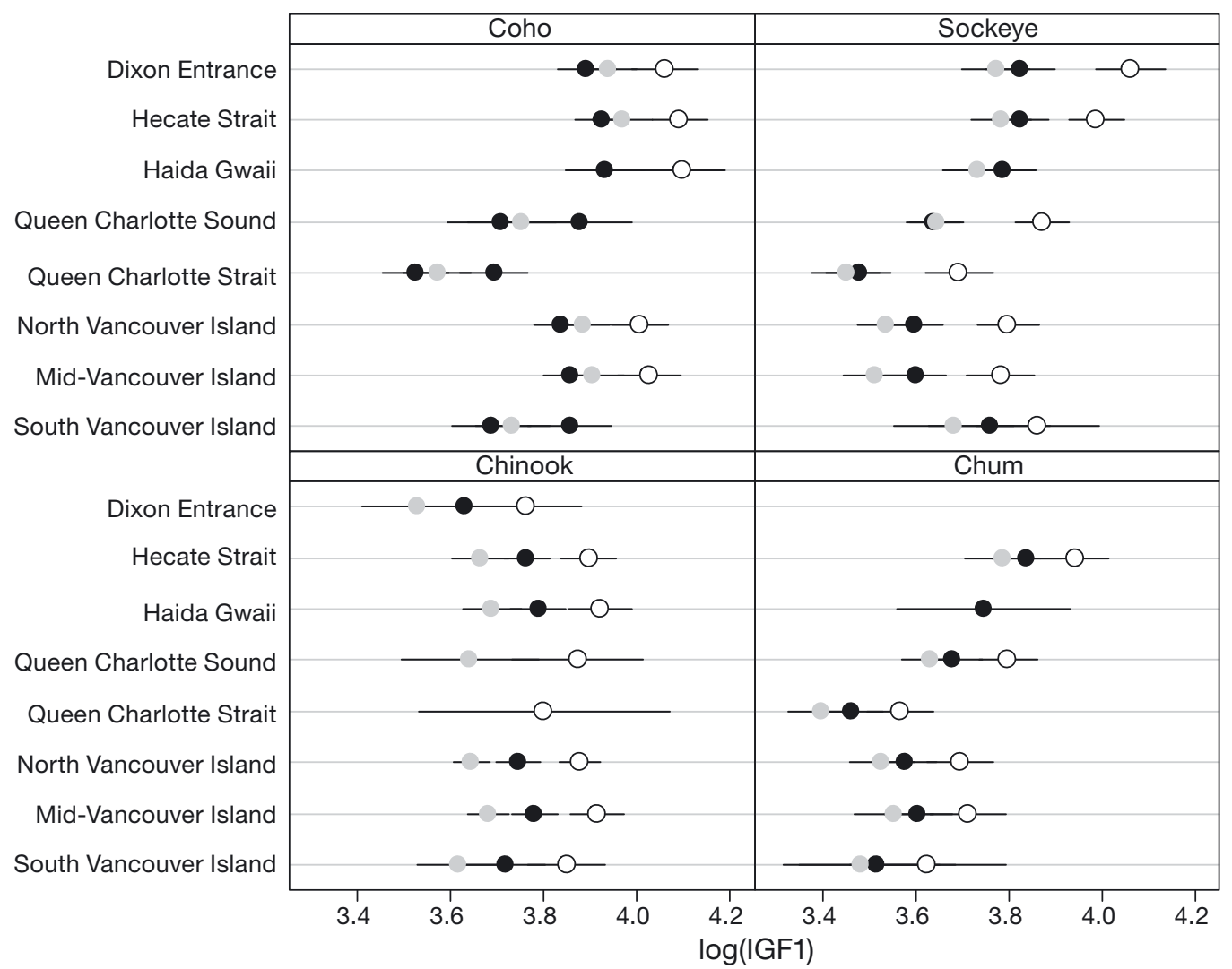

Fig. 5. Oncorhynchus spp. Predicted insulin-like growth factor 1 (IGF1) levels (ng ml-1) (confidence intervals) from the best-fit models of coho, Chinook, sockeye, and chum salmon in 2009 (black), 2010 (gray), and 2011 (white with black outline). Sockeye salmon and chum salmon values are standardized for length-based sampling error 

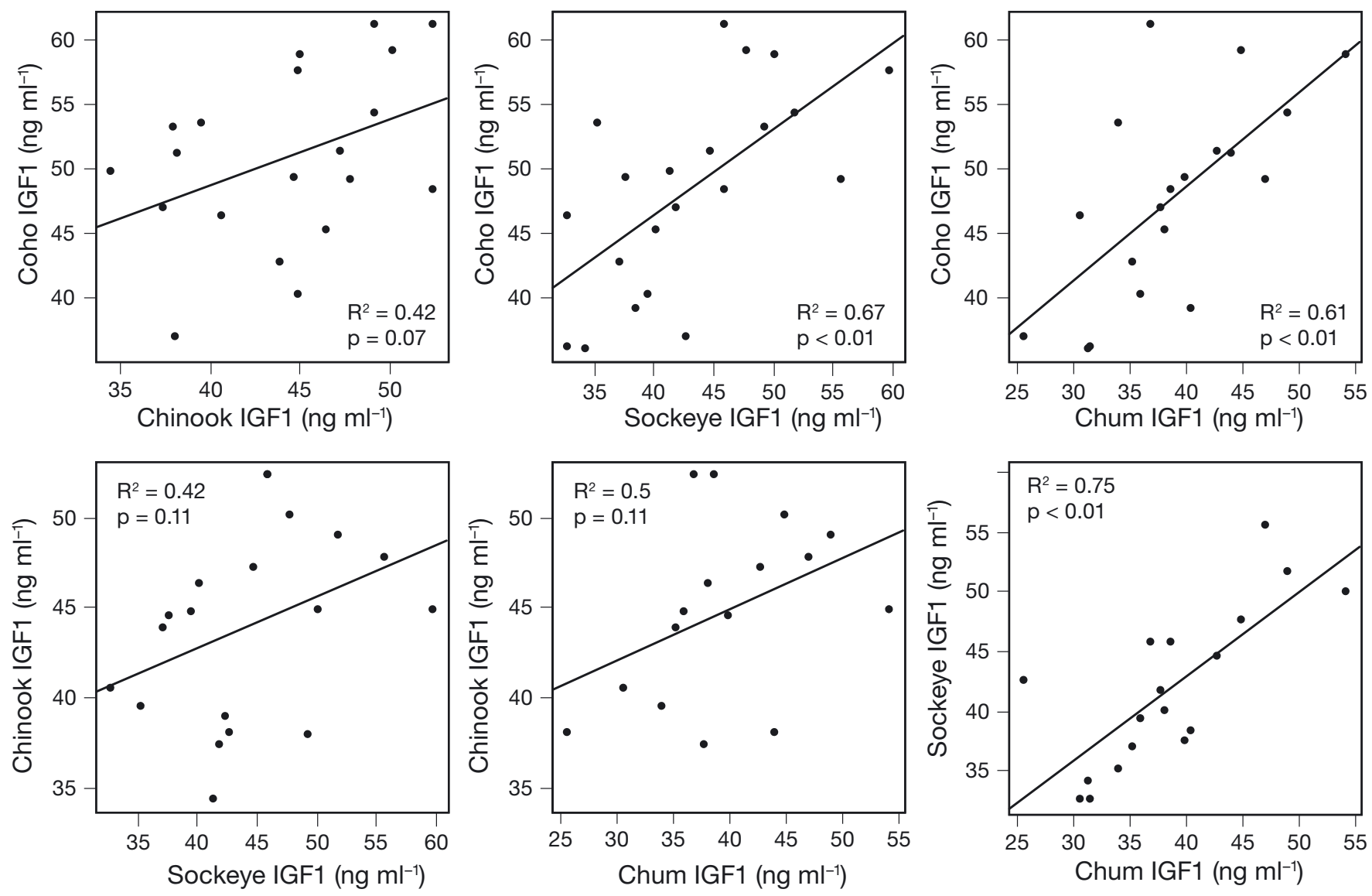

Fig. 6. Oncorhynchus spp. Relationships between coho, Chinook, sockeye, and chum salmon regional mean size-adjusted insulin-like growth factor 1 (IGF1 $1_{\text {Sadj }}$ ) levels $\left(\mathrm{ng} \mathrm{ml}^{-1}\right)$ in 2009, 2010, and 2011. Correlation coefficient ( $\left.\mathrm{R}^{2}\right)$ and significance of relationship (p) are specified in each panel

Island (Perry et al. 1996) and BC (Brodeur et al. 2007). In addition, food consumption of birds that have a prey field similar to juvenile salmon and nest on Triangle Island (northwest coast of Vancouver Island) and Frederick Island (northwest Haida Gwaii), varies inter-annually and regionally (Hedd et al. 2002, Hipfner 2009). Together, these data suggest that salmon may experience regional and inter-annual differences in their prey field composition and abundance, and that this variation may drive differences in juvenile salmon growth.

The significant correlation of IGF $1_{\text {Sadj }}$ levels among coho, sockeye, and chum salmon across regions is probably not due to the absolute abundance of specific prey items in different areas across years. This inference is based on studies showing that the diets of juvenile salmon vary temporally, spatially, and among species (Healey 1991, Perry et al. 1996, Brodeur et al.

Table 5. Oncorhynchus spp. Summary of degrees of freedom (df), AICc values, $\Delta$ AICc values, and adjusted $\mathrm{R}^{2}$ (adj. $\mathrm{R}^{2}$ ) values comparing the fit of models to coho, Chinook, sockeye, and chum salmon insulin-like growth factor 1 (IGF1) data (2009, 2010, and 2011 data are combined in each model). The null model includes length as a fixed effect for sockeye salmon and chum salmon and the intercept only for coho and Chinook salmon

\begin{tabular}{|c|c|c|c|c|c|c|c|c|c|c|c|c|c|c|c|c|}
\hline \multirow[b]{2}{*}{ Model } & \multicolumn{4}{|c|}{ Coho } & \multicolumn{4}{|c|}{ Chinook } & \multicolumn{4}{|c|}{ Sockeye } & \multicolumn{4}{|c|}{ Chum } \\
\hline & $\mathrm{df}$ & $\mathrm{AICc}$ & $\triangle \mathrm{AICc}$ & $\operatorname{adj} \cdot R^{2}$ & $\mathrm{df}$ & $\mathrm{AICC}$ & $\triangle \mathrm{AICC}$ & $\operatorname{adj} . R^{2}$ & $\mathrm{df}$ & $\mathrm{AICC}$ & $\triangle \mathrm{AICC}$ & $\operatorname{adj} . R^{2}$ & $\mathrm{df}$ & $\mathrm{AICC}$ & $\triangle \mathrm{AICC}$ & $\operatorname{adj} . R^{2}$ \\
\hline Null & 3 & 136.22 & 94.29 & 0.32 & 3 & 65.96 & 64.74 & 0.11 & 4 & -247.75 & 128.75 & 0.54 & 4 & -166.09 & 62.66 & 0.55 \\
\hline +Year & 5 & 98.95 & 57.02 & 0.36 & 5 & 1.22 & 0.00 & 0.12 & 6 & -351.70 & 24.80 & 0.59 & 6 & -198.06 & 30.69 & 0.58 \\
\hline +Region & 10 & 82.69 & 40.76 & 0.29 & 10 & 74.21 & 72.99 & 0.06 & 11 & -269.06 & 107.44 & 0.53 & 11 & -196.78 & 31.97 & 0.52 \\
\hline +Year+Region & 12 & 41.93 & 0.00 & 0.33 & 12 & 7.15 & 5.92 & 0.13 & 13 & -376.50 & 0.00 & 0.59 & 13 & -228.75 & 0.00 & 0.55 \\
\hline
\end{tabular}


2007). In particular, diets of juvenile coho salmon tend to be comprised of greater portions of juvenile fish than those of juvenile chum and sockeye salmon (Brodeur \& Pearcy 1990, Brodeur et al. 2007). Landingham et al. (1998) compared food habits of juvenile coho, sockeye, and chum salmon across southeast Alaska and northwest BC and found significant overlap in prey composition between chum and sockeye salmon with a lesser overall overlap of prey species consumed between coho and either chum or sockeye salmon. Thus, correlations in IGF $1_{\text {Sadj, levels among }}$ juvenile coho, sockeye, and chum salmon are broadly consistent with known dietary overlap among these species and are likely due to differences in the overall regional productivity and the related abundance of prey items within the planktonic food web.

Juvenile salmon are positioned at the apex of planktonic food webs, eating larger crustaceans (e.g. amphipods and euphausiids) and small larval/juvenile fishes (Brodeur et al. 2007). Simulation studies (Fulton et al. 2005, Samhouri et al. 2009) conclude that species that feed at this trophic level might be especially useful as marine ecosystem indicators, lending insight into ecosystem productivity, structure, function, or change. Thus differences in IGF1 levels between geographic areas or temporal periods might indicate differing ecosystem properties. The correlations we found in $\mathrm{IGF}_{\text {Sadj }}$ among 3 different species of juvenile salmon, feeding on disparate prey items, suggests that variation in growth of juvenile salmon provides the ability to discriminate among and between marine pelagic ecosystems. Furthermore, based on our results, regional-scale variation in pelagic ecosystem properties exists along the BC coast.

We found higher growth of juvenile sockeye and chum salmon in offshore northern BC waters (Dixon Entrance, Haida Gwaii) than in southern offshore waters (outer Vancouver Island). Freeland (2006) showed that these offshore regions of the continental shelf are subject to variation in large-scale ocean currents, and during our sample years of 2009 through 2011, the division between the Alaska and California Current systems occurred roughly off northern Vancouver Island (Pacific Fisheries Environmental Lab, www.pfeg.noaa.gov/index.html). Previous work has shown higher salmon growth in the northern Alaskan gyre system and lower salmon growth in the California Current system (Hare et al. 1999, Trudel et al. 2007, Wells et al. 2008). Higher growth rates in the Alaskan system have been attributed to the availability of zooplankton (and possibly fish) with higher energetic content, potentially reflected in the higher growth rates of juvenile salmon (Mackas et al. 2007,
Trudel et al. 2007b). Temperature also varies between these 2 current systems and can directly impact salmon growth rate; however, the range of temperatures observed during our sampling period $\left(9-15^{\circ} \mathrm{C}\right.$, unpublished data) are not expected to have large effects on the growth of juvenile salmon (Beauchamp et al. 2007). The IGF1 levels we report thus appear to reflect differences between these large marine ecosystems (California Current and Gulf of Alaska) and suggest that IGF1 measures could be used to demarcate the boundaries between these large oceanographic and biological regions.

Growth of juveniles in Queen Charlotte Strait was consistently the lowest found in a given year for coho, sockeye, or chum salmon across the BC marine waters we surveyed. Queen Charlotte Strait is a geographically constrained area lying between the BC mainland and the northern end of Vancouver Island and is major migratory pathway for juvenile salmon leaving the Strait of Georgia (Groot \& Cooke 1997, Tucker et al. 2009). Our data suggest that food resources for juvenile salmon are limited in this area, as IGF $_{\text {Sadj }}$ levels were significantly lower than those found in other regions. The Johnstone Strait/Queen Charlotte Strait region may represent a foraging challenge for juvenile salmon as they leave the Strait of Georgia and migrate towards Queen Charlotte Sound and the Gulf of Alaska (McKinnell et al. in press). A tremendous amount of tidal mixing occurs as water moves back and forth through Seymour Narrows into and out of the Strait of Georgia, homogenizing the water column. This intense tidal mixing minimizes local primary productivity and presumably disperses any concentrations of juvenile salmon prey. Our results, demonstrating low IGF1 levels in the Queen Charlotte Strait, lend support to these hypotheses.

Given the ecological insights IGF1 levels may provide, sampling has continued in Queen Charlotte Strait (2012-2013, B. Beckman \& M. Trudel unpublished), an area that has generated considerable recent interest in juvenile salmon marine ecology. Several investigators have suggested that oceanographic and biological variation in this and nearby areas was responsible for poor growth and survival of juvenile sockeye salmon in 2007 and resulted in historically poor returns of adult sockeye salmon to the Fraser River in 2009 (Beamish et al. 2012, Thomson et al. 2012, S. McKinnell et al. unpubl.). In addition, several studies have suggested transfer of parasites from net-pen farmed Atlantic salmon to juvenile Pacific salmon that migrate through this region, potentially affecting subsequent growth and survival (Krkošek \& 
Hilborn 2011, Price et al. 2011, but see Marty et al. 2010). The development of a longer-term time series of IGF1 levels in this region will allow us to further examine growth differences in and among these local areas and assess cause and effect relationships between growth and survival of juvenile salmon.

Significant correlations in IGF $1_{\text {Sadj }}$ level among juvenile coho, chum, and sockeye salmon between regions with varying IGF1 $1_{\text {Sadj }}$ levels suggest a tendency for all 3 species to stay within distinct regions for a period of at least $1 \mathrm{wk}$, the time-scale within which a biologically significant difference in IGF1 signal is generated (Beckman 2011). Summertime residency has been documented for coho, chum, and sockeye salmon in local $\mathrm{BC}$, Washington, and Oregon coastal waters (Brodeur et al. 2003, Morris et al. 2007, Tucker et al. 2009, Melnychuk et al. 2010). Furthermore, Tucker et al. (2009) found that the population composition of juvenile sockeye salmon varies among BC regions in June/July catches and reflects local origin of a significant proportion of the fish caught. Fish originating from the west coast of Vancouver Island dominated samples from the west coasts of Vancouver Island and Haida Gwaii $(\sim 60 \%)$. Sockeye salmon from the Fraser River were most abundant $(\sim 80 \%)$ in samples from Queen Charlotte Sound, and Fraser and Nass/Skeena River sockeye salmon were caught in similar abundances in Hecate Strait and Dixon Entrance. Catches of sockeye salmon in all regions comprised a mixture of different populations, and the majority of sockeye salmon caught were locally distributed, related to their rivers of origin. This pattern of variation in catch of different sockeye salmon stocks lends support to the inference that IGF1 levels reflect growth of sockeye salmon in the region in which they were caught.

Juvenile Chinook salmon $\mathrm{IGF}_{\text {Sadj }}$ levels were not significantly correlated with that of other species, suggesting a significant difference in the marine ecology of the juvenile Chinook salmon assessed. The vast majority of Chinook salmon collected during June/July surveys of BC waters are yearling fish from the Columbia River (Tucker et al. 2011, 2012), entering coastal marine waters $\sim 300 \mathrm{~km}$ to the south of the US-Canada border. Columbia River fish almost always comprised more than $50 \%$ of the Chinook salmon catch in every region and in many years comprised almost $100 \%$ of the catch in each region. Thus the majority of Chinook salmon we caught and sampled were probably migrating rapidly northward from the Columbia River through BC to the Gulf of Alaska. The migration rates of yearling Columbia
River Chinook salmon have been calculated at greater than $20 \mathrm{~km} \mathrm{~d}^{-1}$ (Trudel et al. 2009, Tucker et al. 2011, 2012). Thus, Chinook salmon could easily traverse multiple study regions within a week, having the effect of smearing regional differences in productivity over the growth periods reflected in our data and eliminating the possibility of discriminating discrete regional growth signals.

Inter-annual variations in early marine growth rates of juvenile salmon in the Northeast Pacific are correlated to subsequent marine survival rates, including those of sockeye (Farley et al. 2011), chum (Healey 1982), Chinook (Tovey 1999, Tomaro et al. 2012), and coho salmon (Holtby et al. 1990). Furthermore, marine survival rates have been shown to vary spatially on a scale of several hundred kilometers generally in the northeastern Pacific Ocean and specifically, at a similar scale along the BC coast (Mueter et al. 2005, Pyper et al. 2005). The concordance in regional scale of variation in salmon survival and the data presented here suggest that IGF1 measures of juvenile salmon at sea may provide insights into understanding the sources and scale of variation in salmon survival during the early marine period and could enhance our ability to understand mechanisms regulating salmon abundance. Moreover, IGF1 levels themselves may provide an index of marine survival, as it relates to marine growth. Relations between IGF1 and marine survival will be examined as time series are developed for populations for which survival estimates may be generated (requiring enumeration of both freshwater recruits and adult abundance).

Levels of plasma IGF1 have been validated as a growth index in a number of laboratory studies (Beckman 2011) and have been used to document small-scale spatial, seasonal, and inter-annual differences in growth of free-living fish (Beckman et al. 2000, 2004b, Andrews et al. 2011, Beaudreau et al. 2011). Given the novelty of using IGF1 as an ecologically relevant measure of fish growth in a large-scale setting, we compared IGF1 to 2 other commonly used metrics of fish status, viz. size and condition factor, to assess similarities and differences between them. The size of an individual at any one time is the sum of total growth over the lifespan of that individual. As such, size may be an excellent indicator for differences in growth, but at a much greater temporal scale than represented by IGF1 measures. For example, coho and sockeye salmon sampled in Queen Charlotte Strait were among the largest sampled in $\mathrm{BC}$ waters in each year of sampling, yet the IGF1 and IGF1 $1_{\text {Sadj }}$ levels of these fish were among the lowest 
measured in our surveys. Recent growth of coho and sockeye salmon captured in Queen Charlotte Strait $(\sim 1 \mathrm{wk})$, as indexed by IGF1 $1_{\text {Sad }}$ levels, is not correlated with longer-term growth (weeks to months), as indexed by size. The IGF1 $1_{\text {Sadj }}$ levels show that the fish in Queen Charlotte Strait are growing at a relatively slow rate as compared to fish sampled elsewhere. The disjunct relation between IGF1 and size for coho and sockeye salmon caught in Queen Charlotte Strait suggests that these fish either had abnormally high freshwater growth or high early marine growth (prior to entering Queen Charlotte Strait), or that fish captured in Queen Charlotte Strait had migrated into marine waters relatively earlier than fish captured in other regions (a longer period of marine growth). Growth rate and size are intrinsically related over longer time intervals; yet, growth and size can be treated as discretely different attributes over shorter periods, with IGF1 levels reflecting growth during these shorter periods.

We found a significant positive relation between IGF1 and size across individuals for all 4 species. While the degree of variation in IGF1 explained by length was relatively low $\left(\mathrm{r}^{2}=0.10\right.$ to 0.22$)$, we decided to standardize IGF1 levels to size to conservatively assess differences in IGF1 between regions (to minimize Type I errors). The size standardization of IGF1, based on a laboratory assessment of basal IGF1 levels, reduced the relations between IGF $1_{\text {Sadj }}$ and length $\left(\mathrm{r}^{2}=0.04\right.$ to 0.14$)$. We understand that we have assumed that size-IGF1 relations demonstrated in coho salmon (Shimizu et al. 2009) do not differ from those found in sockeye, chum, or Chinook salmon. However, in the absence of data from these other species, we considered it most consistent to make a size correction based on existing biological data rather than to make no size-based correction. Using this precautionary approach, we can state with increased certainty that any observed regional differences in IGF1 $1_{\text {Sadj }}$ reflect differences in growth and that differences were not due to differences in size-related basal IGF1 levels. Whether size adjustment of IGF1 levels is required in future studies depends on the goals of the work, the range in size and age of the fish studied, and the degree of caution desired with regard to discerning differences in length and IGF1. We note that minimizing Type I error increases the risk of Type II error, and in some cases standardizing IGF1 for length might result in underestimating differences in short-term growth rate. We do not consider the IGF1-size standardization used herein necessary for all future use of IGF1 as a growth index.
Condition index, a relative measure of body weight in relation to body length, is commonly used as an index of energy reserves (Jakob et al. 1996, but see Trudel et al. 2005). For all 4 species of salmon, we found at best a weak relationship between IGF1 ${ }_{\text {Sadj }}$ and condition factor, demonstrating that IGF1 represents a different aspect of fish performance than condition factor. Similarly, Andrews et al. (2011) found little relation between IGF1 and condition factor of juvenile lingcod Ophiodon elongatus. Beckman (2011) suggested that IGF1 is best considered an index of growth in length and that IGF1 may not provide a good index of either growth in weight or energy storage. Specifically, changes in length are directly dependent on the actions of IGF1, whereas changes in weight can represent changes in growth of organs (gut, liver) or tissue (adipose) that can vary in their dependence on IGF1. Indices of condition reflect measures of weight relative to length; as such, we might expect little relation of IGF1 to condition factor.

This study introduces a novel tool for assessing salmon growth and ecosystem processes: measures of the hormone IGF1. Sampling juvenile salmon from the coastal marine waters of $\mathrm{BC}$ revealed spatial and inter-annual variation in growth at discrete regional scales. In turn, our data suggest that differences in ecosystem processes existed at these same regional scales. These results have significance for both understanding the marine ecology of juvenile salmon in the Northeast Pacific and for validating a novel ecosystem indicator. Similarly to mapping characters of the ocean environment such as salinity, temperature, or chl $a$, we can now map fish growth. This allows one to directly relate fish growth to other environmental characters within spatial and temporal contexts. Future endeavors include both exploring mechanistic linkages between prey abundance, salmon consumption, and IGF1, and using IGF1 as an index of marine ecosystems, establishing both spatial and interannual variation in tertiary (fish) productivity.

Acknowledgements. We thank D. Harstad, T. Zubkowski, Y.(J.) Jung, M. Thiess, J. Morris, S. Tucker, and the captains and crew of the FV 'Viking Storm' for collecting juvenile salmon and blood samples and L. Rohrbach and S. Nance for processing plasma samples and running laboratory assays. Financial support for this work was provided by Fisheries and Oceans Canada and Bonneville Power Administration to M.T., NOAA Fisheries to B.R.B., the Pacific Salmon Commission through a Southern Fund endowment grant to B.R.B. and M.T., and through a grant from the FATE program of NOAA Fisheries to B.R.B. References to trade names do not imply endorsement by the National Oceanographic and Atmospheric Administration, National Marine Fisheries Service. 


\section{LITERATURE CITED}

Andrews KS, Beckman BR, Beaudreau AH, Larsen DA, Williams GD, Levin PS (2011) Suitability of insulin-like growth factor 1 (IGF1) as a measure of relative growth rates in lingcod. Mar Coast Fish 3:250-260

Batten SD, Walne AW (2011) Variability in northwards extension of warm water copepods in the NE Pacific. J Plankton Res 33:1643-1653

> Beamish RJ, Neville C, Sweeting R, Lange K (2012) The synchronous failure of juvenile Pacific salmon and herring production in the Strait of Georgia in 2007 and the poor return of sockeye salmon to the Fraser River in 2009. Mar Coast Fish 4:403-414

Beauchamp DA, Cross AD, Armstrong JL, Myers KW, Moss JH, Boldt JL, Haldorson LJ (2007) Bioenergetic responses by Pacific salmon to climate and ecosystem variation. North Pac Anadromous Fish Comm Bull 4:257-269

> Beaudreau AH, Andrews KS, Larsen DA, Young G, Beckman BR (2011) Variation in plasma levels of insulin-like growth factor-I (IGF-I) in lingcod: relationships among season, size, and gonadal steroids. Mar Biol 158:439-450

- Beckman BR (2011) Perspectives on concordant and discordant relations between insulin-like growth factor 1 (IGF1) and growth in fishes. Gen Comp Endocrinol 170:233-252

> Beckman BR, Larsen DA, Sharpe C, Lee-Pawlak B, Dickhoff WW (2000) Physiological status of naturally reared juvenile spring chinook salmon in the Yakima River: seasonal dynamics and changes associated with smolting. Trans Am Fish Soc 129:727-753

> Beckman BR, Fairgrieve W, Cooper KA, Mahnken CVW, Beamish RJ (2004a) Evaluation of endocrine indices of growth in individual postsmolt coho salmon. Trans Am Fish Soc 133:1057-1067

Beckman BR, Shimizu M, Gadberry BA, Cooper KA (2004b) Response of the somatotropic axis of juvenile coho salmon to alterations in plane of nutrition with an analysis of the relationships among growth rate and circulating IGF-I and $41 \mathrm{kDa}$ IGFBP. Gen Comp Endocrinol 135: 334-344

Brodeur RD, Pearcy WG (1990) Trophic relations of juvenile Pacific salmon off the Oregon and Washington Coast. Fish Bull 88:617-636

Brodeur RD, Myers KW, Helle JH (2003) Research conducted by the United States on the early ocean life history of Pacific salmon. North Pac Anadromous Fish Comm Bull 3:89-131

Brodeur RD, Fisher JP, Teel DJ, Emmett RL, Casillas E, Miller TW (2004) Juvenile salmonid distribution, growth, condition, origin, and environmental and species associations in the Northern California Current. Fish Bull 102: 25-46

Brodeur RD, Daly EA, Sturdevant MV, Miller TW and others (2007) Regional comparisons of juvenile salmon feeding in coastal marine waters off the west coast of North America. Am Fish Soc Symp 57:183-203

Burnham KP, Anderson DR (2002) Model selection and multimodel inference: a practical information-theoretic approach. Springer, New York, NY

> Crawford WR, Thomson RE (1991) Physical oceanography of the western Canadian continental shelf. Cont Shelf Res 11:669-683

Cuisset B, Pradelles P, Kime DE, Kuhn ER, Babin P, Le Menn F (1994) Enzyme immunoassay for 11-ketotestosterone using acetylcholinesterase as label: application to the measurement of 11-ketotestosterone in plasma of Siberian sturgeon. Comp Biochem Physiol C 108:229-241

Cushing DH (1975) Marine ecology and fisheries. Cambridge University Press, Cambridge

- El-Sabaawi RW, Trudel M, Mackas DL, Dower JF, Maumder A (2012) Interannual variability in bottom-up processes in the upstream range of the California Current system: an isotopic approach. Prog Oceanogr 106:16-27

> Farley EV, Starovoytov A, Naydenko S, Heintz R and others (2011) Implications of a warming eastern Bering Sea for Bristol Bay sockeye salmon. ICES J Mar Sci 68:1138-1146

Fisher J, Trudel M, Ammann A, Orsi J and others (2007) Regional comparisons of distribution and abundance of juvenile salmon along the West Coast of North America. Am Fish Soc Symp 57:31-80

Frank KT, Petrie B, Shackell NL (2007) The ups and downs of trophic control in continental shelf ecosystems. Trends Ecol Evol 22:236-242

Freeland HJ (2006) What proportion of the North Pacific Current finds its way into the Gulf of Alaska? AtmosOcean 44:321-330

- Fulton EA, Smith ADM, Punt AE (2005) Which ecological indicators can robustly detect effects of fishing? ICES J Mar Sci 62:540-551

Groot C, Cooke K (1997) Are the migrations of juvenile and adult Fraser River sockeye salmon (Oncorhynchus nerka) in near-shore waters related? Publ Spec Can Sci Halieut Aquat 96:53-60

Groot C, Margolis L (1991) (eds) Pacific salmon life histories. UBC Press, Vancouver

Hare SR, Mantua NJ, Francis RC (1999) Inverse production regimes: Alaska and West Coast Pacific salmon. Fisheries 24:6-14

> Healey MC (1982) Timing and relative intensity of sizeselective mortality of juvenile chum salmon (Oncorhynchus keta) during early sea life. Can J Fish Aquat Sci 39: 952-957

> Healey MC (1991) Diets and feeding rates of juvenile pink, chum, and sockeye salmon in Hecate Strait, British Columbia. Trans Am Fish Soc 120:303-318

> Hedd A, Ryder JL, Cowen LL, Bertram DF (2002) Interannual variation in the diet, provisioning and growth of Cassin's auklet at Triangle Island, British Columbia: responses to variation in ocean climate. Mar Ecol Prog Ser 229:221-232

> Hipfner JM (2009) Euphausiids in the diet of a North Pacific seabird: annual and seasonal variation and the role of ocean climate. Mar Ecol Prog Ser 390:277-289

Holtby LB, Andersen BC, Kadowaki RK (1990) Importance of smolt size and early ocean growth to interannual variability in marine survival of coho salmon (Oncorhynchus kisutch). Can J Fish Aquat Sci 47:2181-2194

Hunt GL, McKinnell S (2006) Interplay between top-down, bottom-up, and wasp-waist control in marine ecosystems. Prog Oceanogr 68:115-124

> Jakob EM, Marshall SD, Uetz GW (1996) Estimating fitness: a comparison of body condition indices. Oikos 77:61-67

Kostyo JL, Goodman HM (eds) (1999) Handbook of physiology. Section 7: The endocrine system, Vol V: Hormonal control of growth. Oxford University Press, New York, NY

Krkošek M, Hilborn R (2011) Sea lice (Lepeophtheirus salmonis) infestations and the productivity of pink salmon (Oncorhynchus gorbuscha) in the Broughton Archipelago, British Columbia, Canada. Can J Fish Aquat Sci $68: 17-29$ 
Landingham JH, Sturdevant MV, Brodeur RD (1998) Feeding habits of juvenile Pacific Salmon in marine waters of southeastern Alaska and northern British Columbia. Fish Bull 96:285-302

Larsen DA, Shimizu M, Cooper A, Swanson P, Dickhoff WW (2004) Androgen effects on plasma GH, IGF-I, and 41kDa IGFBP in coho salmon (Oncorhynchus kisutch). Gen Comp Endocrinol 139:29-37

Mackas DL, Thomson RE, Galbraith M (2001) Changes in the zooplankton community of the British Columbia continental margin, 1985-1999, and their covariation with oceanographic conditions. Can J Fish Aquat Sci 58: $685-702$

Mackas DL, Batten S, Trudel M (2007) Effects on zooplankton of a warmer ocean: recent evidence from the Northeast Pacific. Prog Oceanogr 75:223-252

Marty GD, Saksida SM, Quinn TJ 2nd (2010) Relationship of farm salmon, sea lice, and wild salmon populations. Proc Natl Acad Sci USA 107:22599-22604

McKinnell S, Curchitser E, Groot K, Kaeriyama M, Trudel M (in press) Oceanic and atmospheric extremes motivate a new hypothesis for variable marine survival of Fraser River sockeye salmon. Fish Oceanogr

Melnychuk MC, Welch DW, Walters CJ (2010) Spatio-temporal migration patterns of Pacific salmon smolts in rivers and coastal marine waters. PLoS ONE 5:e12916

Morris JFT, Trudel M, Thiess ME, Sweeting RM and others (2007) Stock-specific migrations of juvenile coho salmon derived from coded-wire tag recoveries on the continental shelf of western North America. Am Fish Soc Symp 57:81-104

> Mueter FJ, Pyper BJ, Peterman RM (2005) Relationships between coastal ocean conditions and survival rates of northeast Pacific salmon at multiple lags. Trans Am Fish Soc 134:105-119

> Perry RI, Hargreaves NB, Waddell BJ, Mackas DL (1996) Spatial variations in feeding and condition of juvenile pink and chum salmon off Vancouver Island, British Columbia. Fish Oceanogr 5:73-88

Price MHH, Proboszcz SL, Routledge RD, Gottesfeld AS, Orr C, Reynolds JD (2011) Sea louse infection of juvenile sockeye salmon in relation to marine salmon farms on Canada's West Coast. PLoS ONE 6:e16851

Pyper BJ, Mueter FJ, Peterman RM (2005) Across-species comparisons of spatial scales of environmental effects on survival rates of Northeast Pacific salmon. Trans Am Fish Soc 134:86-104

Samhouri JF, Levin PS, Harvey CJ (2009) Quantitative evaluation of marine ecosystem indicator performance using food web models. Ecosystems 12:1283-1298

Shimizu M, Swanson P, Fukada H, Hara A. Dickhoff WW (2000) Comparison of extraction methods and assay validation for salmon insulin-like growth factor-I using commercially available components. Gen Comp Endocrinol 119:26-36

Shimizu M, Cooper KA, Dickhoff WW, Beckman BR (2009) Postprandial changes in plasma growth hormone, insulin, insulin-like growth factor (IGF)-I, and IGF-binding proteins in coho salmon fasted for varying periods. Am J Physiol Regul Integr Comp Physiol 297:R352-R361

Editorial responsibility: Christine Paetzold, Oldendorf/Luhe, Germany
Small BC, Peterson BC (2005) Establishment of a timeresolved fluoroimmunoassay for measuring plasma insulin-like growth factor I (IGF-I) in fish: effect of fasting on plasma concentrations and tissue mRNA expression of IGF-I and growth hormone (GH) in channel catfish (Ictalurus punctatus). Domest Anim Endocrinol 28:202-215

Steele JH (1974) The structure of marine ecosystems. Harvard University Press, Cambridge, MA

Thomson RE, Beamish RJ, Beacham TD, Trudel M, Whitfield PH, Hourston RAS (2012) Anomalous ocean conditions may explain the recent extreme variability in Fraser River sockeye salmon production. Mar Coast Fish 4:415-437

> Tomaro LM, Teel DJ, Peterson WT, Miller JA (2012) When is bigger better? Early marine residence of middle and upper Columbia River spring Chinook salmon. Mar Ecol Prog Ser 452:237-252

Tovey CP (1999) The relationship between marine survival rates of Robertson Creek Chinook Salmon (Oncorhynchus tshawytscha) and their first marine year lengths and growth rates. MSc thesis, University of British Columbia, Vancouver

Trudel MS, Tucker S, Morris JFT, Higgs DA, Welch DW (2005) Indicators of energetic status in juvenile coho salmon (Oncorhynchus kisutch) and chinook salmon (Oncorhynchus tshawytscha). N Am J Fish Manag 25: 374-390

Trudel M, Jones SM, Thiess ME, Morris JFT and others (2007a) Infestations of motile salmon lice on Pacific salmon along the west coast of North America. Am Fish Soc Symp 57:157-182

Trudel M, Thiess ME, Bucher C, Farley EVJ and others (2007b) Regional variation in the marine growth and energy accumulation of juvenile Chinook salmon and coho salmon along the West Coast of North America. Am Fish Soc Symp 57:205-232

Trudel M, Fisher J, Orsi JA, Morris JFT and others (2009) Distribution and migration of juvenile Chinook salmon derived from coded wire tag recoveries along the continental shelf of Western North America. Trans Am Fish Soc 138:1369-1391

Tucker S, Trudel M, Welch DW, Candy JR and others (2009) Seasonal stock-specific migrations of juvenile sockeye salmon along the West Coast of North America: implications for growth. Trans Am Fish Soc 138:1458-1480

Tucker S, Trudel M, Welch DW, Candy JR and others (2011) Life history and seasonal stock-specific ocean migration of juvenile Chinook salmon. Trans Am Fish Soc 140: 1101-1119

Tucker S, Trudel M, Welch DW, Candy JR and others (2012) Annual coastal migration of juvenile Chinook salmon: static stock-specific patterns in a highly dynamic ocean. Mar Ecol Prog Ser 449:245-262

> Ware DM, Thomson RE (2005) Bottom-up ecosystem trophic dynamics determine fish production in the Northeast Pacific. Science 308:1280-1284

Wells BK, Grimes CB, Sneva JG, McPherson S, Waldvogel JB (2008) Relationships between oceanic conditions and growth of Chinook salmon (Oncorhynchus tshawytscha) from California, Washington, and Alaska, USA. Fish Oceanogr 17:101-125

Submitted: October 4, 2013; Accepted: January 10, 2014 Proofs received from author(s): March 16, 2014 